\title{
Intellectual Capital as a Factor Forming Economic Security of Enterprises in Society 5. 0
}

\author{
MISHCHUK IEVGENIIA \\ Department of Accounting, Taxation, Public Management and Administration \\ Kryvyi Rih National University \\ 11 Vitaliy Matusevych Str., Kryvyi Rih, 50027 \\ https://orcid.org/0000-0003-4145-3711 \\ UKRAINE \\ RIABYKINA YEKATERYNA \\ Kryvyi Rih National University \\ 11 Vitaliy Matusevych Str., Kryvyi Rih, 50027 \\ https://orcid.org/0000-0001-7747-558X \\ UKRAINE \\ USHENKO NATALYA \\ Department of Finance and Economics \\ Borys Grinchenko Kyiv University \\ 18/2 Bulvarno-Kudriavska Str., Kyiv, 04053 \\ https://orcid.org/0000-0002-3158-4497 \\ UKRAINE
}

Department of Enterprise Economics, Organization and Management of enterprises

\section{HAMOVA OKSANA}

Department International Economics, Natural Resources and Economics of International Tourism

Zaporizhzhia National University

66 Zhukovsky Str., Zaporizhzhia, 69600

https://orcid.org/0000-0002-9752-6900

UKRAINE

\author{
TKACHENKO SERGII \\ Department of Mechanics \\ Zaporizhzhia Polytechnic National University \\ 64 Zhukovsky Str., Zaporizhzhia, 69063 \\ https://orcid.org/ 0000-0002-3798-5902 \\ UKRAINE \\ YASTREMSKA NATALIA \\ Department of State and Legal Disciplines \\ Donetsk State University of Internal Affairs \\ 21 S. Tilgyi Str., Kryvyi Rih, 50065 \\ https://orcid.org/0000-0002-4867-9652 \\ UKRAINE
}

Abstract: - The article shows that in Society 5.0 intellectual capital is a key factor forming economic security
of enterprises. The priority of structural components of intellectual capital as a factor of enterprise economic
security formation is determined. Features of mining and beneficiation enterprises operation are considered
while structuring intellectual capital. The resulting criteria for assessing efficiency of the intellectual capital use
during economic security formation are established. Three key groups of competences of personnel necessary 
for economic security formation are identified. It is substantiated that organic connection of intellectual capital structural elements will enable forming economic security of the enterprise during the current period and providing economic security parameters in the long term. Based on the data obtained from mining and beneficiation enterprises, it is demonstrated that this will be possible due to growth of an innovative level of technological processes which will contribute to product quality enhancement that, in turn, will expand the client base.

Key-Words: - Competences of personnel, Digital competence, Economic security, Intellectual capital, Society 5.0.

Received: July 29, 2021. Revised: December 20, 2021. Accepted: January 13, 2022. Published: January 14, 2022.

\section{Introduction}

With the onset of economic instability caused by the Covid-19 pandemic, the threats associated with human capital have risen from the eleventh to the first position in the list of threats to long-term growth. Therefore, employees of the new digital generation are the basis for long-term growth of individual enterprises and countries as a whole. In Ukraine, $59 \%$ of enterprise managers prefer investing in human capital development but not in acquisition of new technologies, while worldwide the ratio is radically different: $67 \%$ prefer investing in acquisition of new technologies, 33\% - in development of their personnel's skills and abilities [1]. However, in Society 5.0, intellectual capital as well as information and communications enabling formation of economic security of enterprises in both the short and long term is increasingly becoming the most important and sought-after factors. The growing importance of intellectual capital as a factor forming economic security of enterprises makes it one of priority objects of research.

The theoretical and practical aspects of intellectual capital management are dealt with in works by many scientists, in particular T.V. Baulina [2], K.V. Kovtunenko [3], A.O. Tkachenko [4], Ya.O. Topilnytska [5]. The issues under research are gaining significance considering a specific character of enterprise operation in various sectors of the economy. Certain elements of the intellectual capital management system of mining and beneficiation enterprises are covered in works by O.M. Vakulchyk, H.L. Stupniker (relationship of innovation potential and intellectual capital) [6], R.V. Korolenko (determination of planned and actual indicators of human capital) [7].

Society 5.0 is a new socio-economic paradigm within which a consensus of integrating social and environmental priorities into technological innovations is distinguished [8]. The degree of such integration determines the external environment and the environment of the enterprise's operation and impacts the processes of its economic security formation. In this regard, every enterprise that strives for sustainable development in the long term should first consider development of modern analytics, big data technologies, artificial intelligence, implementation of robotics in every type of activities, automation of business processes and use of the Internet of Things [9]. In Society 5.0, application of the above technologies has wider purposes than just profit gaining. Priority tasks include dealing with environmental and social problems as well. However, to solve the tasks, enterprises of the future should already employ personnel with digital competences [10].

The impact of innovations and shared value creation on the process of transition from Industry 4.0 to Society 5.0 is discussed in [11]. In [12], expected performance of open data is defined as a critical factor for models of introducing user technologies for future implementation of open data in Industry 4.0 and impacts the sphere of Society 5.0. [13] considers directions of the search for the best solutions to implement Society 5.0 for the Sustainable Development Goals through development of the policy based on factual data using artificial intelligence.

Thus, modern literature contains developments in both the field of intellectual capital and various aspects of Society 5.0. At the same time, we have not found any works dealing with the issue of their combination and, moreover, consideration of intellectual capital as a factor forming economic security of enterprises in Society 5.0. Therefore, due to its significance in terms of practical value for managers, owners of enterprises and society as a whole, this problem requires solution and is dealt with in this article.

\section{Problem Formulation}


The profit-oriented approach to formation and provision of economic security in the long term is becoming unsound. In Society 5.0, a narrow profit orientation no longer prevails as it does not allow considering environmental and social costs, the level of which impacts security of stakeholders [14]. In such a society, the purpose of forming economic security of industrial enterprises should simultaneously include economic, social and environmental aspects. Such integration of the three basic aspects involves availability of innovations aimed at not only maximizing profits, but also solving social and environmental problems, as well as improving security of all groups of stakeholders of the enterprise: investors, customers, the local community, employees, etc. To do this, industrial enterprises should be sustainable and economically secure. The state of economic security in the long term is characterized by resource efficiency, decreased energy consumption, reduction of greenhouse gas emissions, and waste minimization. Intellectual capital of the enterprise plays a crucial role in forming security both in the current and strategic dimensions. Without it, innovations and technologies will not work [15].

Thus, a shift of the focus from economic drivers of formation of economic security of the enterprise to human capital is an important characteristic that distinguishes Society 5.0 as an external environment and that of enterprise operation. An employee in Society 5.0 is treated not as a "value", but as a carrier of intellectual potential and as an investment position of the enterprise. Due to that, both the enterprise and the employee can develop. Employees should have more opportunities, and the work environment should become more inclusive. For this, employees should have competences that will provide the opportunity to actively participate in development and implementation of new technologies.

Intellectual capital does not have specific units of measurement due to its intangibility. This generates the problem of analyzing efficiency of its impact on the process of enterprise economic security formation. Specifics of mining and beneficiation enterprises makes it impossible to use the most common approaches to such intellectual capital estimation (Table 1).

Table 1. Disadvantages of using traditional approaches to assessing efficiency of use of intellectual capital of mining and beneficiation enterprises

\begin{tabular}{|l|l|lc|}
\hline Approach & \multicolumn{2}{|c|}{ Essence } & \multicolumn{2}{c|}{ Disadvantages } \\
\hline Direct & Based on & The & priority \\
\hline
\end{tabular}

\begin{tabular}{|c|c|c|}
\hline $\begin{array}{l}\text { intellectual } \\
\text { capital } \\
\text { methods }\end{array}$ & $\begin{array}{l}\text { direct } \\
\text { monetary } \\
\text { valuation of } \\
\text { various } \\
\text { components } \\
\text { of } \\
\text { intellectual } \\
\text { capital }\end{array}$ & $\begin{array}{l}\text { components of } \\
\text { intellectual capital of } \\
\text { mining and } \\
\text { beneficiation } \\
\text { enterprises are digital } \\
\text { competences which } \\
\text { cannot be evaluated. IT } \\
\text { capital share in the } \\
\text { asset structure is } \\
\text { critically low. }\end{array}$ \\
\hline $\begin{array}{l}\text { Return on } \\
\text { assets } \\
\text { methods }\end{array}$ & $\begin{array}{l}\text { Based on the } \\
\text { difference } \\
\text { between } \\
\text { enterprise } \\
\text { profitability } \\
\text { and average } \\
\text { industry } \\
\text { profitability }\end{array}$ & $\begin{array}{l}\text { High dependence of } \\
\text { financial results of } \\
\text { mining } \\
\text { beneficiation } \\
\text { enterprises on market } \\
\text { fluctuations; inability } \\
\text { to isolate a lack of } \\
\text { profit resulted from } \\
\text { inefficient use of } \\
\text { intellectual capital in } \\
\text { accounting practice }\end{array}$ \\
\hline $\begin{array}{l}\text { Scorecard } \\
\text { methods }\end{array}$ & $\begin{array}{l}\text { Include use } \\
\text { of various } \\
\text { indices and } \\
\text { indicators } \\
\text { that may } \\
\text { impact the } \\
\text { intellectual } \\
\text { capital value }\end{array}$ & $\begin{array}{l}\text { Impossibility to } \\
\text { adequately assess } \\
\text { digital competence of } \\
\text { personnel through } \\
\text { expert opinion which is } \\
\text { the base for forming } \\
\text { relevant indices and } \\
\text { indicators. }\end{array}$ \\
\hline
\end{tabular}

Source: customized by the authors on the basis of [16]

The authors of the article adhere to the traditional division of intellectual capital into human, structural and client types. However, we emphasize the need to prioritize these components, considering specific features of enterprise operation in various industries.

Thus, there are theoretical and methodological problems that consist in the following:

- little attention is paid to intellectual capital as a factor that forms economic security of the enterprise. It is not practically considered from this point of view;

- intellectual capital is intangible, so it cannot be quantified. Due to this, development of indicators for concluding on efficiency of intellectual capital application to form economic security of the enterprise is challenging.

In view of the above, the article aims to study intellectual capital as a factor forming economic security of the enterprise in Society 5.0.

\section{Problem Solution}




\subsection{Prioritization of Intellectual Capital Components for Economic Security Formation}

The role of intellectual capital as a factor forming economic security of the enterprise in Society 5.0 should be presented as shown in Fig. 1 .

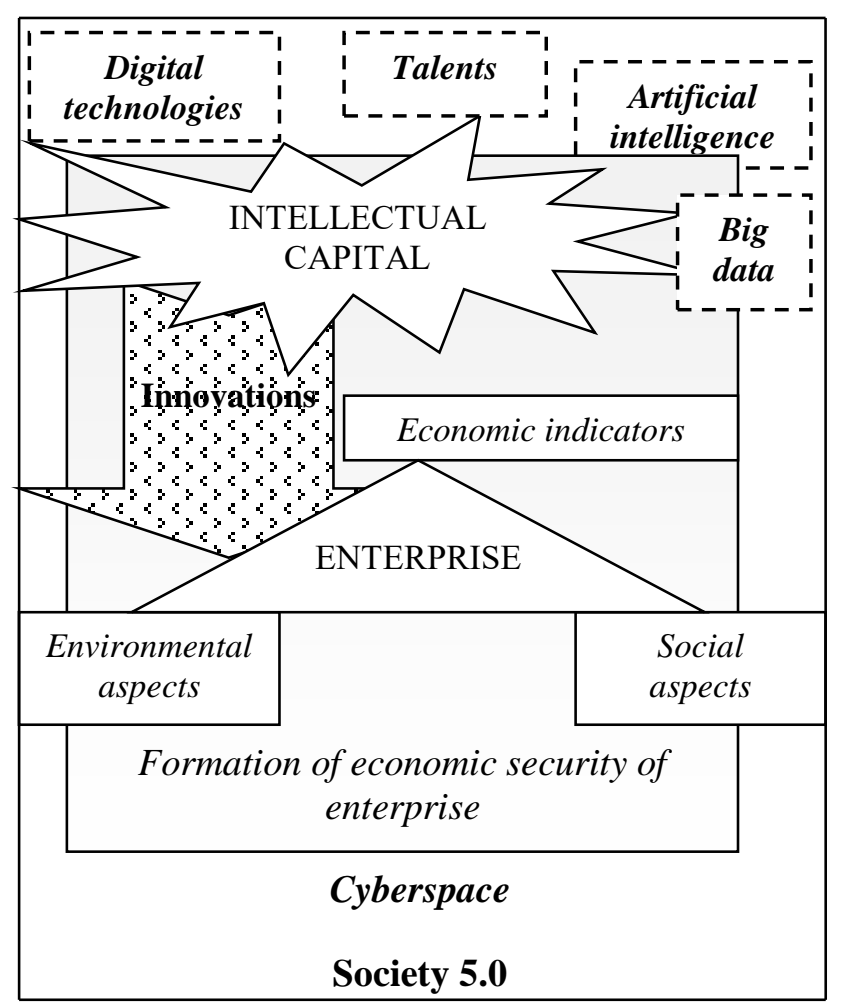

Fig. 1: The role of intellectual capital as a factor forming economic security of the enterprise in Society 5.0 (Source: developed by Ie. Mishchuk)

To determine priority of components of intellectual capital of mining and beneficiation enterprises (human, structural and client capital), the authors adapt a methodological approach proposed in [17] to rate significance of company's strategic resources. For each structural component of intellectual capital, a square and inverse matrix of paired comparisons with a single main diagonal is formed according to $[16 ; 17]$ :

$$
\|a i j\|
$$

where $a i j=1$ with a as one of the structural components of intellectual capital;

$i, j=1, \ldots, n$ are the number of structural components. As the authors support the traditional approach implying division into human, structural and client capital (as mentioned above), then $n=3$.
Next, the authors calculate the components of the matrix vector with further normalization by the formulas:

$$
\begin{gathered}
\mathrm{a}_{n}=\left(\prod_{j=1}^{n} \mathrm{a}_{\mathrm{nj}}\right)^{1 / n}, \\
K_{n}=\frac{\mathrm{a}_{n}}{\sum_{i}^{n} \mathrm{a}_{i}} .
\end{gathered}
$$

For quantitative measurement of the priority, the authors apply the method of paired comparisons based on the following comparison scale described in [16]:

1,2 - almost similar priority of structural components;

3,4 - moderate predominance of one component;

5, 6 - significant predominance;

7,8 - very significant predominance;

9,10 - incommensurable predominance.

The obtained results presented in Fig. 2 demonstrate priority of human capital formed by personnel's key competences.

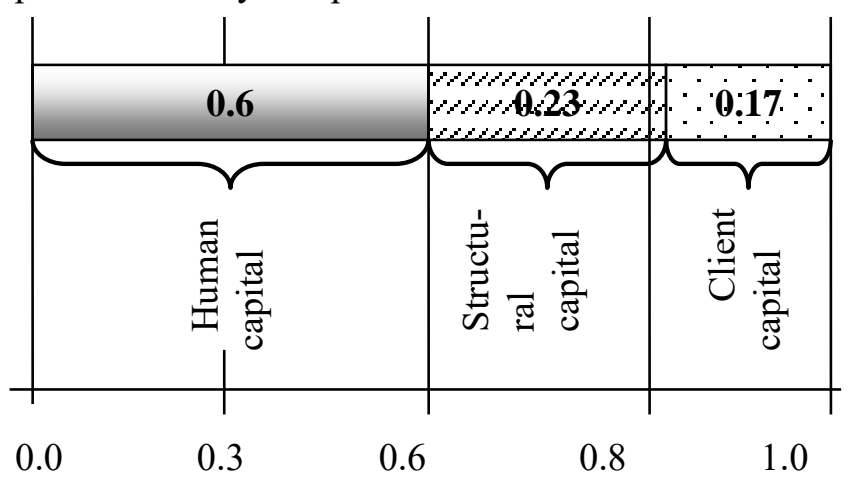

Fig. 2: Priority of structural components of intellectual capital of Ukraine's mining and beneficiation enterprises (Source: [16])

These very components contribute to formation of economic security of the enterprise. In addition, they provide operational excellence and market stability of the enterprise, this results in increased resistance of the enterprise to external threats.

\subsection{Determination of Personnel's Competences Required for Economic Security Formation}

The next step involves determining the competences personnel should possess to effectively participate in economic security formation. While analyzing, we apply the European Council Recommendation on Key Competences for Lifelong Learning [18]. 
The authors' critical comprehension of personnel's competences necessary for forming economic security of enterprises makes it possible to distinguish three key groups of competences:

1) Personal, social and learning competence becomes especially important under distance work as it involves the ability to effectively manage time and information as well as realizing internal states, cooperating constructively with other people, remaining steadfast and managing learning and career;

2) Digital competence includes digital and information literacy, communication and cooperation, data analytics, digital content creation, cybersecurity, as well as work with new technologies and attention to data;

3) Entrepreneurship competence involves the ability to plan and manage projects and is based on skills of creativity, critical thinking, problem solving, initiative, insistence and the ability to cooperate. Qualities that characterize entrepreneurship include initiative, activity, search, courage and commitment to success. It includes the willingness to motivate others and appreciate one's own and other people's ideas, empathize with and take care of people and the world, and take responsibility for ethics throughout the process [18].

Based on the above approach, digital competence of personnel is determined as priority in forming economic security of enterprises (Fig. 3).

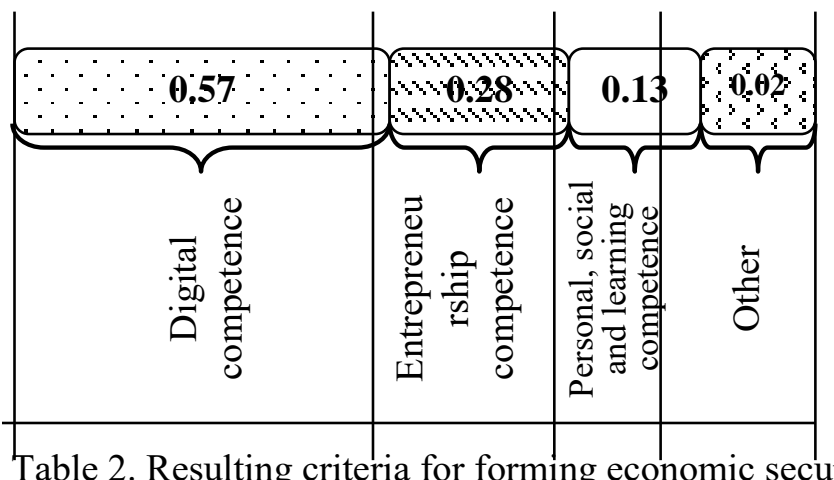

0.0

0.5

$0.75 \quad 0.85$

Fig. 3: Priority of personnel's key competences necessary for forming economic security of mining and beneficiation enterprises (Source: developed by the authors)

It should be noted that personnel's digital competences not only impact enterprise economic security formation but also contribute to security of the personnel themselves (higher professionalism implies higher wages, reduced risks of dismissal, etc.). Distinction between these two types of security is detailed in [19].

\subsection{Methodical Approach to Determining Resulting Indicators of Enterprise Economic Security and Its Practical Testing at Mining and Beneficiation Enterprises of Ukraine}

To understand how well intellectual capital is used to form economic security at the enterprise, the resulting criteria should be specially developed. Here, it is imperative to consider specifics of the enterprise's activities, i.e. the features that impact its economic activity. In order to demonstrate how this can be done, we have compiled a table that takes into account main features of mining and beneficiation enterprise operation. The table shows features that are inherent in all enterprises of the mining industry. Further on, targets in economic security formation are determined. These targets are contrasted with those components of intellectual capital that are most used to achieve them, as well as the results that the enterprise should receive in the end. These achievements are the resulting criteria for economic security formation (Table 2). with the priority components of intellectual capital

\begin{tabular}{|c|c|c|c|}
\hline $\begin{array}{l}\text { Specific features of } \\
\text { mining and benefi- } \\
\text { ciation enterprises } \\
\text { operation }\end{array}$ & $\begin{array}{l}\text { Targets in economic security } \\
\text { formation }\end{array}$ & $\begin{array}{l}\text { Priority } \\
\text { components } \\
\text { of intellect- } \\
\text { tual capital } \\
\end{array}$ & Resulting criteria \\
\hline $\begin{array}{l}\text { Dependence on natural } \\
\text { capital }\end{array}$ & $\begin{array}{l}\text { The most comprehensive use of } \\
\text { mineral resources. Decreased } \\
\text { environmental stress. }\end{array}$ & $\begin{array}{l}\text { Human } \\
\text { capital }\end{array}$ & $\begin{array}{l}\text { Concentrate yield. Iron recovery } \\
\text { Ore losses and dilution. } \\
\text { The level of technological processes } \\
\text { innovation }\end{array}$ \\
\hline $\begin{array}{l}\text { Limited price maneuver- } \\
\text { ring }\end{array}$ & $\begin{array}{l}\text { Growth of qualitative parameters of } \\
\text { products }\end{array}$ & \multirow[t]{2}{*}{$\begin{array}{c}\text { Structural } \\
\text { capital }\end{array}$} & Iron content in final products \\
\hline $\begin{array}{l}\text { Commonality of } \\
\text { products }\end{array}$ & Reduction of production costs. & & $\begin{array}{l}\text { Growth rate of highly processed } \\
\text { products }\end{array}$ \\
\hline $\begin{array}{l}\text { High dependence on the } \\
\text { world market of iron ore }\end{array}$ & $\begin{array}{c}\text { Optimization of business relations } \\
\text { with consumers }\end{array}$ & $\begin{array}{l}\text { Client } \\
\text { capital }\end{array}$ & Client base stability \\
\hline
\end{tabular}


Source: [16]

\section{products}

The resulting indicators for the analysis of efficiency of intellectual capital use when forming economic security of mining and beneficiation enterprises may be presented by a wider group than that shown in Table 2. In particular, [20] presents other criteria that can also be used for our research. For instance, resulting indicators that reflect environmental stresses, the degree of air and soil emission reduction, etc. can make another direction of research [14].

However, in this article we only focus on those indicators in Table 2, as our intention is to demonstrate methods of forming such criteria and the way they can be used. That is why, in this case the quantity of indicators does not matter.

Based on the annual financial statements and data of financial departments of mining and beneficiation enterprises, the authors perform calculations and present the results in Table 3.

Table 3. Resulting criteria of efficiency of using intellectual capital of mining and beneficiation enterprises when forming their economic security, 2016-2020.

\begin{tabular}{|c|c|c|c|c|c|}
\hline Enterprise & 2016 & 2017 & 2018 & 2019 & 2020 \\
\hline \multicolumn{6}{|c|}{ Concentrate yield } \\
\hline $\begin{array}{l}\text { PJSC } \\
\text { "Inguletsky } \\
\text { mining and } \\
\text { beneficiation } \\
\text { plant" }\end{array}$ & 38.3 & 38.5 & 39.1 & 39.4 & 41.6 \\
\hline $\begin{array}{l}\text { JSC } \\
\text { "Southern } \\
\text { mining and } \\
\text { beneficiation } \\
\text { plant" }\end{array}$ & 37.8 & 37.5 & 37.9 & 39.1 & 39.8 \\
\hline $\begin{array}{l}\text { PJSC } \\
\text { "Northern } \\
\text { mining and } \\
\text { beneficiation } \\
\text { plant" }\end{array}$ & 37.9 & 38.1 & 38.6 & 39.2 & 39.3 \\
\hline $\begin{array}{l}\text { PJSC } \\
\text { "Central } \\
\text { mining and } \\
\text { beneficiation } \\
\text { plant" }\end{array}$ & 38.4 & 38.8 & 39.6 & 39.9 & 42.4 \\
\hline \multicolumn{6}{|c|}{ Level of technological processes innovation } \\
\hline $\begin{array}{l}\text { PJSC } \\
\text { "Inguletsky } \\
\text { mining and } \\
\text { beneficiation } \\
\text { plant" }\end{array}$ & 0.202 & 0.20 & 0.198 & 0.199 & 0.203 \\
\hline $\begin{array}{l}\text { JSC } \\
\text { "Southern } \\
\text { mining and }\end{array}$ & 0.164 & 0.171 & 0.169 & 0.172 & 0.175 \\
\hline
\end{tabular}

\begin{tabular}{|c|c|c|c|c|c|}
\hline $\begin{array}{l}\text { beneficiation } \\
\text { plant" }\end{array}$ & & & & & \\
\hline $\begin{array}{l}\text { PJSC } \\
\text { "Northern } \\
\text { mining and } \\
\text { beneficiation } \\
\text { plant" }\end{array}$ & 0.186 & 0.187 & 0.182 & 0.184 & 0.187 \\
\hline $\begin{array}{l}\text { PJSC } \\
\text { "Central } \\
\text { mining and } \\
\text { beneficiation } \\
\text { plant" }\end{array}$ & 0.208 & 0.21 & 0.203 & 0.206 & 0.208 \\
\hline \multicolumn{6}{|c|}{ Iron ore raw materials marketability } \\
\hline $\begin{array}{l}\text { PJSC } \\
\text { "Inguletsky } \\
\text { mining and } \\
\text { beneficiation } \\
\text { plant" }\end{array}$ & 0.86 & 0.87 & 0.86 & 0.87 & 0.87 \\
\hline $\begin{array}{l}\text { JSC } \\
\text { "Southern } \\
\text { mining and } \\
\text { beneficiation } \\
\text { plant" }\end{array}$ & 0.88 & 0.88 & 0.88 & 0.88 & 0.88 \\
\hline $\begin{array}{l}\text { PJSC } \\
\text { "Northern } \\
\text { mining and } \\
\text { beneficiation } \\
\text { plant" }\end{array}$ & 0.90 & 0.90 & 0.90 & 0.90 & 0.90 \\
\hline $\begin{array}{l}\text { PJSC } \\
\text { "Central } \\
\text { mining and } \\
\text { beneficiation } \\
\text { plant" }\end{array}$ & 0.90 & 0.90 & 0.91 & 0.91 & 0.91 \\
\hline \multicolumn{6}{|c|}{ Level of information provision } \\
\hline $\begin{array}{l}\text { PJSC } \\
\text { "Inguletsky } \\
\text { mining and } \\
\text { beneficiation } \\
\text { plant" }\end{array}$ & 0.728 & 0.718 & 0.74 & 0.605 & 0.768 \\
\hline $\begin{array}{l}\text { JSC } \\
\text { "Southern } \\
\text { mining and } \\
\text { beneficiation } \\
\text { plant" }\end{array}$ & 0.783 & 0.788 & 0.697 & 0.702 & 0.707 \\
\hline $\begin{array}{l}\text { PJSC } \\
\text { "Northern } \\
\text { mining and } \\
\text { beneficiation } \\
\text { plant" }\end{array}$ & 0.683 & 0.781 & 0.783 & 0.695 & 0.762 \\
\hline $\begin{array}{l}\text { PJSC } \\
\text { "Central } \\
\text { mining and } \\
\text { beneficiation } \\
\text { plant" }\end{array}$ & 0.635 & 0.649 & 0.644 & 0.663 & 0.707 \\
\hline \multicolumn{6}{|c|}{ Client base stability } \\
\hline $\begin{array}{l}\text { PJSC } \\
\text { "Inguletsky } \\
\text { mining and }\end{array}$ & 0.705 & 0.705 & 0.704 & 0.703 & 0.705 \\
\hline
\end{tabular}




\begin{tabular}{|l|l|l|l|l|l|}
\hline $\begin{array}{l}\text { beneficiation } \\
\text { plant" }\end{array}$ & & & & & \\
\hline $\begin{array}{l}\text { JSC } \\
\text { "Southern } \\
\text { mining and } \\
\text { beneficiation } \\
\text { plant" }\end{array}$ & 0.831 & 0.829 & 0.798 & 0.713 & 0.701 \\
\hline $\begin{array}{l}\text { PJSC } \\
\text { "Northern } \\
\text { mining and } \\
\text { beneficiation } \\
\text { plant" }\end{array}$ & 0.911 & 0.910 & 0.891 & 0.892 & 0.889 \\
\hline $\begin{array}{l}\text { PJSC } \\
\text { "Central } \\
\text { mining and } \\
\text { beneficiation } \\
\text { plant" }\end{array}$ & 0.910 & 0.912 & 0.912 & 0.911 & 0.911 \\
\hline
\end{tabular}

Source: calculated by the authors based on the data from [21-24] and financial departments of the enterprises

The total action of the three key groups of personnel competences increases concentrate output at mining and beneficiation enterprises. Thus, zero decrease of this indicator over the past three years allows concluding that the level of human capital use does not provoke decrease of efficient use of mineral and raw materials base. Concentrate output rise at all the enterprises under study is a positive trend resulted from implementation of innovative solutions in the production process. Iron losses during concentration lead to decreased efficiency of enterprise activities caused by reduced volumes of iron ore products from $1 \mathrm{t}$ of run-of-mine ore [16].

It is a well-known fact that mining and beneficiation enterprises apply traditional technologies of iron ore extraction and concentration. These technologies remain almost unchanged from the moment of their development, excluding the ones at the PJSC "Inguletsky mining and beneficiation plant" where a comparatively new technology of flotation has been implemented. As a result, the level of innovation of technological processes is recognized as low in comparison with world standards. Implementation of digital competence does not fundamentally change the technology itself, but only increases its efficiency.

The degree of iron ore products marketability does not reach reference values. Today, products with iron content of $67-68 \%$ and with silica content up to $4-5 \%$ [25] are competitive on the world market. According to two determinant criteria of iron ore products (iron content and silica content), Ukrainian enterprises are outsiders. This conclusion is based on the data from [16] and the results of comparing corresponding indicators from [21-24; 26].

Structural capital as a set of data processing systems presents a basis for achieving targets of forming economic security of enterprises in the long term. The authors' understanding of information provision as a prerequisite for creating a single information field that combines enterprise management subsystems provides for assessment of the coefficient of compliance with the present-day level. In current conditions, the enterprises under study have a sufficiently developed information and management system, within which the software package "SAP for Mining" developed by German specialists is widely applied. Reserves for raising the information provision level include introduction of a software module for optimizing managerial decision-making [16; 27], as well as digitalization measures which are widely covered in many works, in particular in [11].

Almost similar experience of management at the enterprises under study, product commonality, their favorable geographical location near mineral deposits make it possible to note that they have approximately the same level of business reputation. Therefore, in terms of stakeholder security formation, it is worth focusing on stability of client connections. Quality indicators of iron ore products of all Ukrainian manufacturers are slightly different, i.e. consumers can freely change suppliers. The decreased level of the client base stability at all the enterprises under study is caused by decreased exports due to negative consequences of protectionist measures in the context of the Covid19 pandemic. Extraordinary from an economic point of view growth of China's metallurgical industry enables switching supplies of Ukrainian iron ore products to Southeast Asian and others markets. This switch will also have a positive impact on the country's economy as according to [28], foreign trade is a driver of economic growth.

\section{Conclusion}

It is not expedient to determine strategic economic security of enterprises based on calculation of capitalization, profit and other traditional financial indicators. Profitability can be achieved by various means including use of non-renewable resources, business reputation impacts, minimization of losses and reduction of costs, increase of production volumes, etc. Formation of Society 5.0 contributes to achievement of economic indicators considering provision of security of employees' and other groups of stakeholders' interests. This, in turn, 
impacts economic security formation and provision. Here, intellectual capital of the enterprise becomes a key factor.

Formation of economic security of enterprises is impossible without involvement and efficient use of intellectual capital. This draws exceptional attention to accumulation of personnel's competences, which are referred to as "three key competence groups" in the present article, on the one hand, and to the organizational and investment aspects of introducing innovations into the production process on the other hand. Organic connection of intellectual capital structural elements will enable:

- forming economic security of the enterprise in the current period;

- providing economic security parameters (operational excellence and market sustainability) in the long term. The example of mining and beneficiation enterprises demonstrates that this will be possible due to growth of an innovative level of technological processes, which will contribute to product quality enhancement that, in turn, will expand the client base in markets of Western Europe, Southeast Asia and other promising markets.

Enterprises should pay more attention to education, professional development and, if necessary, re-training of their employees and top managers to strengthen, first of all, their digital competences, as well as personal, social and learning and entrepreneurship competences.

Thus, the approach outlined in the article can be used by enterprises of various fields of activity and sectors of the economy. To do this, it is sufficient to consider other features of these enterprises' operation and other targets in economic security formation and on this basis to build a new comparison matrix necessary to achieve the determined targets of intellectual capital components. New resulting criteria can be obtained in this way.

Development of methods for evaluating the efficiency of investing in intellectual capital of the enterprise according to the criterion of the economic security level makes the direction of further research. We plan to develop methods which can be used for estimating the amount money to be invested in intellectual capital development to increase the level of economic security of the enterprise.

\section{References:}

[1] Report KPMG. New normality, 2020 URL: https:/home.kpmg/ua/uk/home/insights/2020/0 8/kpmg-reviewmagazine-new-normality.html

[2] Baulina T.V. Intellectual capital: a strategic resource for the transformation of national economy: monograph, Kyiv: MNTU Yu. Bugaya, Vyshemirsky Publishing House, 2009, $276 \mathrm{p}$.

[3] Kovtunenko K.V. The main approaches to the formation of intellectual capital: content and role in the innovative development of the enterprise, Development economics, No. 3, 2013, pp. $59-62$.

[4] Tkachenko A.O. The concept and structure of intellectual capital of the enterprise, Development Management, No.12, 2013, pp. 27-29.

[5] Topilnytska Ya.O. Features of modern management of intellectual capital joint-stock companies, Bulletin of the Odessa National University, Economy, No. 2(1), 2013, pp. 171174.

[6] Vakulchyk O.M., Stupniker H.L. Determining the value of intellectual capital as a factor of innovative activity of enterprises of the mining and metallurgical complex, Economic Bulletin of the National Mining University, No. 4, 2008, pp. 53- 60 .

[7] Korolenko R.V. Study of human capital shortage in mining and processing plants Kryvbas, European vector of economic development, No. 2, 2013, pp. 133-140.

[8] Potocan V., Mulej M., Nedelko Z. Society 5.0: Balancing of Industry 4.0, economic advancement and social problems, Kybernetes No. 50, 2020, pp. 794-811.

[9] Shkarlet S., Dubyna M., Shtyrkhun K., Verbivska L. Transformation of the Paradigm of the Economic Entities Development in Digital Economy, WSEAS. Transactions on Environment and Development, Vol. 16, 2020, pp. 413-422.

[10] Mishchuk Ie., Rebrova S., Krush P., Zinchenko D., Astafieva K. Digitalization security as a marker of modern mechanical engineering technology implementation in the context of ensuring strategic economic security of enterprises, WSEAS. Transactions on Business and Economics, Vol. 18, 2021, pp. 117-125.

[11] Aquilani B., Piccarozzi M., Abbate T., Codini A. The Role of Open Innovation and Value Co-creation in the Challenging Transition from Industry 4.0 to Society 5.0: Toward a Theoretical Framework, Sustainability, No. 12, 2020, pp. 8943. 
[12] Shiroishi Y., Uchiyama K. and Suzuki N. Society 5.0: for human security and well-being, Computer, Vol. 51, No. 7, 2018, pp. 91-95.

[13] Shiroishi Y., Uchiyama K. and Suzuki, N. Better actions for society 5.0: using AI for evidence based policy making that keeps humans in the loop, Computer, Vol. 52, No. 11, 2019, pp. 73-78.

[14] Mishchuk Ie., Nusinov V., Polischuk S., Kutova N., Stolietova I. Assessment of Environmentally-Oriented Stakeholders Coherent Security as a Prerequisite of Sustainable Enterprise Development and the Role of Non-Financial Statements in that Regard, Academy of Accounting and Financial Studies Journal. Vol. 25 (1), 2021, pp. 1-10.

[15] Mishchuk I., Serdiuk O., Bekhter L., Bondarenko, O. Ensuring security of economic and informational interests of mining enterprises taking into account innovative technological trends, Eastern-European Journal of Enterprise Technologies, No. 2(13 (110), 2021, pp. 42-54. DOI: 10.15587/17294061.2021.230308

[16] Ischenko M.I. Resource determinants of financial and economic performance enterprises, Bulletin of the Kryvyi Rih Economic Institute of the Kyiv National University, No. 2, 2013, pp. 29-36.

[17] Nusinov V.J., Ryabykina K.G. Intellectual capital management efficiency mining enterprises, Scientific notes, No. 16, 2014, pp. 180-186.

[18] ANNEX to the Proposal for a Council Recommendation on Key Competences for Lifelong Learning, 2021 URL: https://ec.europa.eu/education/sites/education/fi les/annex-recommendation-key-competenceslifelong-learning.pdf.

[19] Mishchuk Ie., Zinchenko Ol., Zinchenko D., Pawliszczy D., Pohrebniak An. Differences in the Assessment of Economic Security of Personnel and Security of Enterprise Staff Interests, WSEAS. Transactions on Environment and Development, Vol. 16, 2020, pp. 454-463.

[20] Nusinov V. Ya., Mishchuk Ie. V. Elaboration of scientific and methodological approaches to providing economic security of an enterprise as a key component of its management. Scientific Journal "Economic Horizons", No. 4(11), 2019, pp. $93-105$.

[21] Official site PJSC "Inguletsky mining and beneficiation plant": Annual reporting. URL: https://ingok.metinvestholding.com/ua/about/in fo

[22] Official site JSC "Southern mining and beneficiation plant": Annual reporting. URL: https://www.ugok.com.ua/ua/about/info.php

[23] Official site JSC "Northern mining and beneficiation plant": Annual reporting. URL: https://sevgok.metinvestholding.com/ru/about/i nfo

[24] Official site JSC "Central mining and beneficiation plant": Annual reporting. URL: https://cgok.metinvestholding.com/ru/about/inf o

[25] Helevachuk Z.J. Positioning of domestic mining enterprises on world market for iron ore products, Formation of a market economy, Business Economics: Theory and Practice, 2012, pp. 63-72.

[26] Iron ore mining in the world and in Russia. Portal for subsoil users. URL: https://dprom.online/metallurgy/dobychazheleznoj-rudy-v-mire-i-v-rossii/

[27] Nusinov V.Ya., Varava A.A. Organizational principles of creating a strategic information subsystem management in the conditions of mining and processing enterprises of Ukraine, Economics of industry, No. 3-4, 2012, pp. 201207.

[28] Alikhanli Ye. Granger Causality Analysis of Foreign Trade Impact on Economic Growth: Case of Azerbaijan, WSEAS. Transactions on Environment and Development, Vol. 16, 2020 pp. 384-389.

\section{Contribution of Individual Authors to the Creation of a Scientific Article (Ghostwriting Policy)}

Mishchuk Ievgeniia developed ideas, including substantiated the role of intellectual capital as a factor forming economic security of the enterprise, exhibited connections with Society 5.0, distinguished three key competence groups;

Riabykina Yekateryna prioritized structural components of intellectual capital;

Ushenko Natalya studied specifics of Society 5.0;

Hamova Oksana specified disadvantages of applying traditional methods to assessing intellectual capital of mining and beneficiation enterprises;

Tkachenko Sergii collected financial and managerial data on the mining and beneficiation enterprises under study and did the calculations;

Yastremska Natalia studied specific features of mining and beneficiation enterprise operation.

\section{Creative Commons Attribution License 4.0} (Attribution 4.0 International, CC BY 4.0)

This article is published under the terms of the Creative Commons Attribution License 4.0

https://creativecommons.org/licenses/by/4.0/deed.en $\underline{\underline{U S}}$ 